\title{
Impak Komunikasi terhadap Penerimaan Inovasi Penanaman Padi
}

\author{
(Communication Impact Towards Innovation on Paddy Plantation)
}

\author{
Shahrina Md Nordin \\ (Jabatan Pengurusan dan Kemanusiaan, Universiti Teknologi PETRONAS) \\ Ammar Redza Ahmad Rizal \\ Junaida Yahya \\ (Pusat Inovasi Sosial, Universiti Teknologi PETRONAS)
}

ABSTRAK

Penanaman padi merupakan industri tanaman makanan utama negara Malaysia. Pembaharuan dan inovasi merupakan elemen penting yang menambahbaik industri ini. Pengenalan teknologi baharu dan inovasi dipengaruhi oleh pelbagai faktor termasuklah komunikasi. Penggunaan komunikasi berkesan berupaya meningkatkan penyebaran inovasi di dalam pelbagai bidang. Kajian ini memperlihatkan impak komunikasi terhadap inovasi di dalam penanaman padi. Tiga aspek utama iaitu peranan dan penglibatan pesawah, pengetahuan dan maklumat pesawah serta pengurusan inovasi dalam konteks komunikasi diteliti kesannya terhadap penerimaan inovasi dalam kalangan pesawah. Kajian ini dilaksanakan ke atas para pesawah di negeri Perak melibatkan seramai 150 orang responden. Hasil kajian mendapati komunikasi memainkan peranan penting terhadap penerimaan inovasi oleh pesawah. Pemilihan saluran komunikasi yang betul akan menambah baik penerimaan inovasi. Cadangan penambahbaikan dalam konteks komunikasi turut dipaparkan di akhir penulisan ini.

Kata kunci: Komunikasi; inovasi; pesawah; padi; Malaysia

ABSTRACT

Paddy plantation is an important industry in Malaysia. Advancement and innovation are important elements in improving this industry. Introduction of new technology and innovation are influenced by several factors including communication. The use of effective communication could possibly increase the innovation diffusion in multiple sectors. This study looks on the impact of communication towards innovation on paddy plantation. Three important aspects which include role of farmers, knowledge and information of the farmers and innovation management in the context of communication were investigated to understand its impacts towards innovation acceptance among farmers. This research was undertaken among farmers in Perak which involved 150 paddy farmers as respondents. The findings revealed that communication plays an important role towards acceptance of innovation among the paddy farmers. Selection of the correct communication channel increases the innovation acceptance. Suggestions to improve communication are also added in the last section of this study.

Keywords: Communication; innovation; diffusion; paddy; Malaysia

\section{PENDAHULUAN}

Dalam Rancangan Malaysia Kesembilan (RMK-9) yang telah dilancarkan oleh kerajaan pada tahun 2006, kerajaan Malaysia mula mengorak langkah dan memfokuskan sektor pertanian ke arah sistem pertanian maju dan lestari. Transformasi yang dijalankan memerlukan pembudayaan dari segi penggunaan teknologi di kalangan petani di negara ini.

Pelbagai kaedah yang telah diguna pakai untuk meningkatkan hasil tanaman padi di negeri Perak. Pihak kerajaan secara amnya amat komited untuk mentransformasikan sektor penanaman padi ke arah sektor yang lebih moden, dinamik, inovatif dan kompetitif. Untuk meningkatkan pertumbuhan positif sektor penanaman padi di negeri Perak, kerjasama daripada semua pihak amat diperlukan untuk menjadikan Malaysia sebagai negara pengeluar hasil pertanian yang berkualiti tinggi.
Kajian terdahulu menunjukkan terdapatnya permasalahan komunikasi antara pesawah dan pegawai pengembangan pertanian (Shahrina, Noor \& Saad 2014). Dalam erti kata lain, terdapat maklumat terutamanya yang berkaitan dengan inovasi dan penambahbaikan yang tidak dapat disampaikan kepada para pesawah. Oleh yang demikian, permasalahan ini merupakan salah satu faktor yang membawa kepada kelembapan penerimaan teknologi oleh golongan pesawah. Komunikasi membolehkan pemahaman maklumat yang merupakan elemen utama di dalam sesebuah inovasi. Pemahaman maklumat membolehkan pesawah mengetahui dengan lebih lanjut mengenai sesuatu inovasi dan membolehkan mereka membandingkan kelebihan relatif sesuatu inovasi. Langkah ini adalah perkara teras di dalam difusi inovasi dan penerimaan teknologi terbaharu (Rogers 2003). Tanpa penggunaan komunikasi yang sesuai, penerimaan maklumat tidak akan berlaku seterusnya merencatkan proses difusi inovasi. 